\title{
A convenient four-component one-pot strategy toward the synthesis of pyrazolo[3,4-d]pyrimidines
}

\author{
Mingxing Liu, Jiarong Li, Hongxin Chai, Kai Zhang, Deli Yang, Qi Zhang and Daxin Shi
}

\author{
Full Research Paper \\ Address: \\ School of Chemical Engineering and Environment, Beijing Institute of \\ Technology, Beijing, 100081, China \\ Email: \\ Daxin Shi ${ }^{*}$ - shidaxin@bit.edu.cn. \\ * Corresponding author \\ Keywords: \\ four-component; one-pot; pyrazolo[3,4- $d$ ]pyrimidine; sodium alkoxide
}

Beilstein J. Org. Chem. 2015, 11, 2125-2131.

doi:10.3762/bjoc.11.229

Received: 24 August 2015

Accepted: 29 October 2015

Published: 06 November 2015

Associate Editor: J. P. Wolfe

() 2015 Liu et al; licensee Beilstein-Institut.

License and terms: see end of document.

\begin{abstract}
An efficient one-pot synthesis of pyrazolo[3,4- $d]$ pyrimidine derivatives by the four-component condensation of hydrazines, methylenemalononitriles, aldehydes and alcohols has been developed via two different reaction pathways. The structures of target products were characterized by IR spectroscopy, NMR $\left({ }^{1} \mathrm{H}\right.$ and $\left.{ }^{13} \mathrm{C}\right)$ spectroscopy and HRMS (ESI) spectrometry. The crystal structure of 4-ethoxy-6-(2-nitrophenyl)-1-phenyl-1H-pyrazolo[3,4- $d]$ pyrimidine was determined by single crystal X-ray diffraction.
\end{abstract}

\section{Introduction}

Heterocycles containing a pyrimidine ring are extensively present in natural products and are very important because of their biological activity [1-6]. They have shown a wide range of pharmacological potential such as kinase inhibitors [1], antitumor [7,8], anti-inflammatory [9,10], antimicrobial [11-13], pesticides [14], radio protectant [15] and cardiovascular activity $[16,17]$. For example, ibrutinib, sildenafil, allopurinol and zaleplon are famous pyrazolopyrimidine drugs.

Because of the importance of pyrazolo[3,4- $d]$ pyrimidines, many methods for the synthesis of pyrazolo[3,4- $d]$ pyrimidines have been explored. Some examples include the condensation of 5-aminopyrazole-4-carbonitrile with amides [18-21], carboxylic acids [22-24], amidines [25,26], nitriles [27,28], ketones [29,30] and halohydrocarbon [31], the cyclization of 5-aminopyrazole- 4-carboxamides with amides [32], ureas [33-36], esters [37-39] and acyl chloride [40], and the reaction of aminopyrazoles and amides [41,42].

In our previous studies, dihydropyrimidinone was synthesized through the condensation of 5-aminopyrazole-4-carbonitrile and ketones [29,30]. 5-Aminopyrazole-4-carbonitrile was prepared from the reaction of ethoxymethylenemalononitrile with phenylhydrazine in a step-wise fashion [43-47]. During the course of previous studies, we envisioned that we could combine these reactions and embarked on designing a strategy toward a one-pot synthesis by combining the three reactants. When benzaldehyde was used as the reactant, the target product was obtained (Scheme 1A). But when benzaldehyde was switched to anisaldehyde, the expected product was not 
A:<smiles>NNc1ccccc1</smiles><smiles>CCOC=C(C#N)C#N</smiles><smiles>O=Cc1ccccc1</smiles><smiles>CCCCCO</smiles><smiles>O=c1[nH]c(-c2ccccc2)nc2c1cnn2-c1ccccc1</smiles>

B:<smiles>NNc1ccccc1</smiles><smiles></smiles><smiles>COc1ccc(C=O)cc1</smiles>
$\underset{\mathrm{C}_{2} \mathrm{H}_{5} \mathrm{OH}}{\stackrel{\mathrm{NaOH}}{\longrightarrow} 60^{\circ} \mathrm{C}}$<smiles>CCOc1nc(-c2ccc(OC)cc2)nc2c1cnn2-c1ccccc1</smiles>

Scheme 1: The synthesis of pyrazolo[3,4-d]pyrimidines.

obtained and pyrazolo $[3,4-d]$ pyrimidines was isolated (Scheme 1B). Inspired by this phenomenon, we conducted detailed studies and found a new convenient synthesis of pyrazolo[3,4- $d]$ pyrimidines. To the best of our knowledge, this is a novel methodology for the synthesis of pyrazolo[3,4- $d]$ pyrimidines by the reaction of hydrazines, methylenemalononitriles, aldehydes and alcohols. During the preparation of this manuscript, Liu et al. reported the synthesis of pyrazolo[3,4- $d]$ pyrimidines from 5-aminopyrazole-4-carbonitrile [48]. The differences between their and our strategy are that we developed a four-component combined reaction to synthesize pyrazolo[3,4$d$ ]pyrimidines, the catalyst that we use is different, the universality of the substrates are very broad and the substrates are more readily available.

\section{Results and Discussion}

Phenylhydrazine, 2-(ethoxymethylene)malononitrile, ethanol and benzaldehyde were selected as the model reactants. The influence of the reaction conditions was studied and the results are summarized in Table 1. No target product was afforded in

Table 1: Optimization of the reaction conditions ${ }^{\mathrm{a}}$.

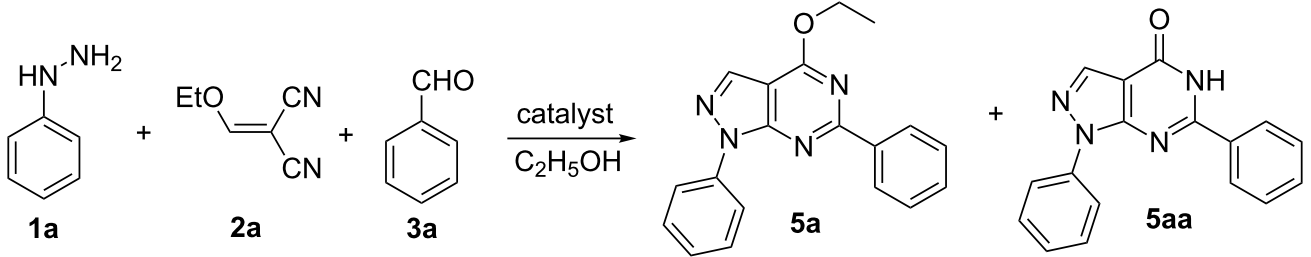

\begin{tabular}{|c|c|c|c|c|}
\hline Entry & Solvent & Cat. (eqiv.) & Temp. $\left({ }^{\circ} \mathrm{C}\right)$ & Yield $(\%)^{b}$ \\
\hline 1 & $\mathrm{EtOH}$ & - & 60 & 0 \\
\hline 2 & $\mathrm{EtOH}$ & $\mathrm{Na}_{2} \mathrm{CO}_{3}(1.2)$ & 60 & 0 \\
\hline 3 & $\mathrm{EtOH}$ & $\mathrm{NaOH}(1.2)$ & 60 & 82 (5aa) \\
\hline 4 & $\mathrm{EtOH}$ & DBU (1.2) & reflux & $42(5 a)$ \\
\hline 5 & $\mathrm{EtOH}$ & $\mathrm{NaH}(1.2)$ & 60 & $62(5 a)$ \\
\hline 6 & $\mathrm{EtOH}$ & $\mathrm{NaOEt}(1.2)$ & 60 & $85(5 a)$ \\
\hline 7 & DMSO & $\mathrm{NaOEt}(1.2)$ & 60 & $57(5 a)$ \\
\hline 8 & toluene & NaOEt (1.2) & 60 & $70(\mathbf{5 a})$ \\
\hline 9 & 1,4-dioxane & $\mathrm{NaOEt}(1.2)$ & 60 & $35(5 a)$ \\
\hline 10 & $\mathrm{EtOH}$ & NaOEt (1.2) & 25 & $63(5 a)$ \\
\hline 11 & $\mathrm{EtOH}$ & NaOEt (1.2) & reflux & $85(5 a)$ \\
\hline 12 & $\mathrm{EtOH}$ & $\mathrm{NaOEt}(0.5)$ & 60 & $47(5 a)$ \\
\hline 13 & $\mathrm{EtOH}$ & NaOEt (2.0) & 60 & $85(5 a)$ \\
\hline
\end{tabular}

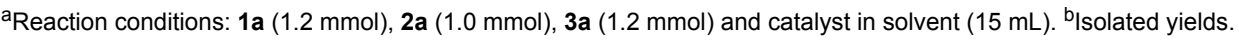


the presence of an inorganic weak base or without a catalyst (Table 1, entries 1 and 2). Sodium hydroxide could catalyze this reaction, but pyrazolo[3,4- $d]$ pyrimidinone 5aa was obtained instead of pyrazolo[3,4- $d]$ pyrimidine 5a (Table 1, entry 3 ). This shows that the catalytic properties of sodium hydroxide have some limitations. Fortunately, some strong bases could promote the reaction to produce 5a, though DBU needed a higher reaction temperature (Table 1, entries 4-6). Taking into account the yield of the reaction, sodium alkoxide was the best choice. The reaction performed in alcohol resulted in the highest yield (Table 1, entries 6-9). The reaction temperature was screened and the appropriate temperature was found to be $60{ }^{\circ} \mathrm{C}$ (Table 1 , entries 6, 10 and 11). The amount of catalyst had an effect on the reaction and 1.2 equivalents of sodium alkoxide was the most appropriate choice (Table 1, entries 12 and 13). This means that sodium alkoxide is not only a catalyst, but also participates in the reaction.

A series of hydrazines, methylenemalononitriles, aldehydes and alcohols were investigated under the optimal reaction conditions. As shown in Figure 1, the influence of different aldehydes on the reaction was studied first. The results show that aldehydes with substituents such as $p-\mathrm{MeO}, p-\mathrm{Me}, 3,4,5-$ $(\mathrm{MeO})_{3}, 2-\mathrm{MeO}-5-\mathrm{Br}, m-\mathrm{NO}_{2}$ and $o-\mathrm{NO}_{2}$ are all compatible

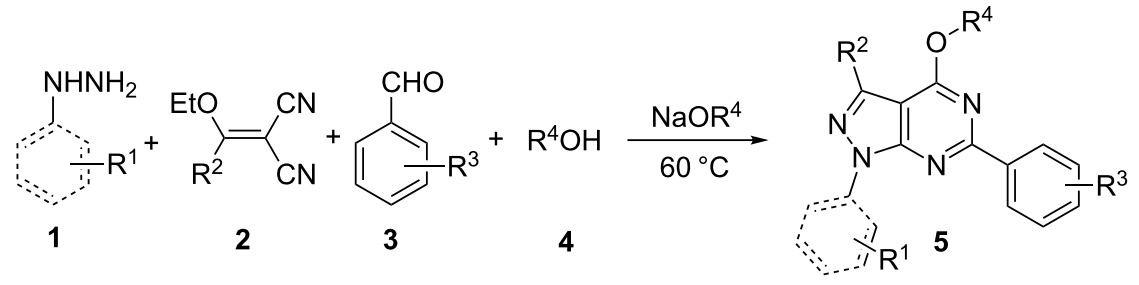<smiles>CCOc1nc(-c2ccccc2)nc2c1cnn2-c1ccccc1</smiles>

5a, $85 \%$<smiles>CCOc1nc(-c2ccc(OC)cc2)nc2c1cnn2-c1ccccc1</smiles>

5b, $90 \%$<smiles>CCOc1nc(-c2ccc(C)cc2)nc2c1cnn2-c1ccccc1</smiles>

5c, $85 \%$<smiles>CCOc1nc(-c2cc(OC)c(OC)c(OC)c2)nc2c1cnn2-c1ccccc1</smiles>

5d, $81 \% \quad \mathrm{OCH}_{3}$<smiles>CCOc1nc(-c2cc(Br)ccc2OC)nc2c1cnn2-c1ccccc1</smiles><smiles>CCOc1nc(-c2cccc([N+](=O)[O-])c2)nc2c1cnn2-c1ccccc1</smiles><smiles>C/C=C(/C)n1ncc2c(OCC)nc(-c3ccccc3)nc21</smiles>

$5 i, 84 \%$<smiles>CCOc1nc(-c2ccccc2)nc2c1cnn2C</smiles>

5j, $79 \%$<smiles>CCOc1nc(-c2ccccc2[N+](=O)[O-])nc2c1cnn2-c1ccccc1</smiles>

$5 \mathbf{g}, 78 \%$<smiles>CCOc1nc(-c2ccccc2)nc2c1c(C)nn2C</smiles>

5 k, $75 \%$<smiles>CCOc1nc(-c2ccccc2)nc2c1cnn2-c1ccc(Cl)cc1</smiles><smiles>COc1ccc(-c2nc(OC)c3cnn(-c4ccccc4)c3n2)cc1</smiles>

$51,87 \%$<smiles>CCCOc1nc(-c2ccccc2)nc2c1cnn2-c1ccccc1</smiles><smiles>CC(C)Oc1nc(-c2ccccc2)nc2c1cnn2-c1ccccc1</smiles>

Figure 1: Four-component one-pot synthesis of 5 . Reactions conditions: $\mathbf{1}(1.2 \mathrm{mmol}), \mathbf{2}(1.0 \mathrm{mmol}), \mathbf{3}(1.2 \mathrm{mmol})$ and $\mathbf{4}(1.2 \mathrm{mmol})$ in alcohol $(15 \mathrm{~mL})$. 
under optimal conditions. The corresponding products were obtained in good yield (Figure 1, 5a-g). Then a set of hydrazines were selected and the target products were obtained. However, the yield of aromatic hydrazines bearing electronwithdrawing groups or electron-donating groups was higher than that of methylhydrazine (Figure $1, \mathbf{5 h}-\mathbf{j}$ ). This is possibly due to the electronic effect of the substituents. Though the steric hindrance could affect the reaction, 3-substituted pyrazolo[3,4$d]$ pyrimidine was also obtained in good yield (Figure 1, 5k). In order to further broaden the scope of this one-pot methodology, a series of alcohols such as methanol, $n$-butanol, $n$-propanol and isopropanol were investigated. The expected products were also obtained in good yield (Figure 1, 5i-p). This fact revealed the universality and advantages of this method for the synthesis of pyrazolo[3,4-d]pyrimidines.

To rationalize the possible reaction mechanism, we successfully separated three intermediates (6a, 7a and 5aa). 4-Ethoxy1,6-diphenyl-1 $H$-pyrazolo[3,4- $d]$ pyrimidine (5a) was obtained from the condensation of 5-amino-1-phenyl-1H-pyrazole-4carbonitrile (6a) with benzaldehyde and ethanol, the cyclization of (E)-5-(benzylideneamino)-1-phenyl-1H-pyrazole-4carbonitrile (7a) with ethanol or the reaction of 1,6-diphenyl1,5-dihydro-4H-pyrazolo[3,4- $d]$ pyrimidin-4-one (5aa) with ethanol, respectively (Scheme 2).

With those results in hand, two possible reaction mechanisms were proposed and shown in Scheme 3. 5-Aminopyrazole-4carbonitrile $\mathbf{6}$ was obtained from the reaction of hydrazine $\mathbf{1}$ and methylenemalononitrile $\mathbf{2}$ through nucleophilic addition, cyclization and aromatization. The nucleophilic attack of the amino group of $\mathbf{6}$ on the carbonyl group of the aldehyde affords 7. Then 7 provides the target product via two different reaction pathways. The first route is that 7 loses a water molecule to afford the Schiff base $\mathbf{8}$. Then $\mathbf{8}$ undergoes a Pinner reaction and imine 9 is formed, and then $\mathbf{9}$ turns into $\mathbf{1 0}$ through intramolec- ular cyclization. Finally, $\mathbf{1 0}$ is oxidized to give pyrazolo[3,4d]pyrimidine 5. Another route is that 7 undergoes an intramolecular Pinner reaction to form $\mathbf{1 1}$. Then 11 rearranges to dihydropyrazolo[3,4- $d$ ]pyrimidin-4-ones 13 via Dimroth rearrangement and $\mathbf{1 3}$ is oxidized to provide $\mathbf{1 4}$ [49]. Finally, 14 undergoes a nucleophilic addition and loses a water molecule to afford the final product $\mathbf{5}$.

All products were characterized by IR, ${ }^{1} \mathrm{H}$ NMR, ${ }^{13} \mathrm{C}$ NMR and HRMS. A final confirmation of the structure of the reaction product $\mathbf{5 g}$ was determined by X-ray diffraction (Figure 2) [50].

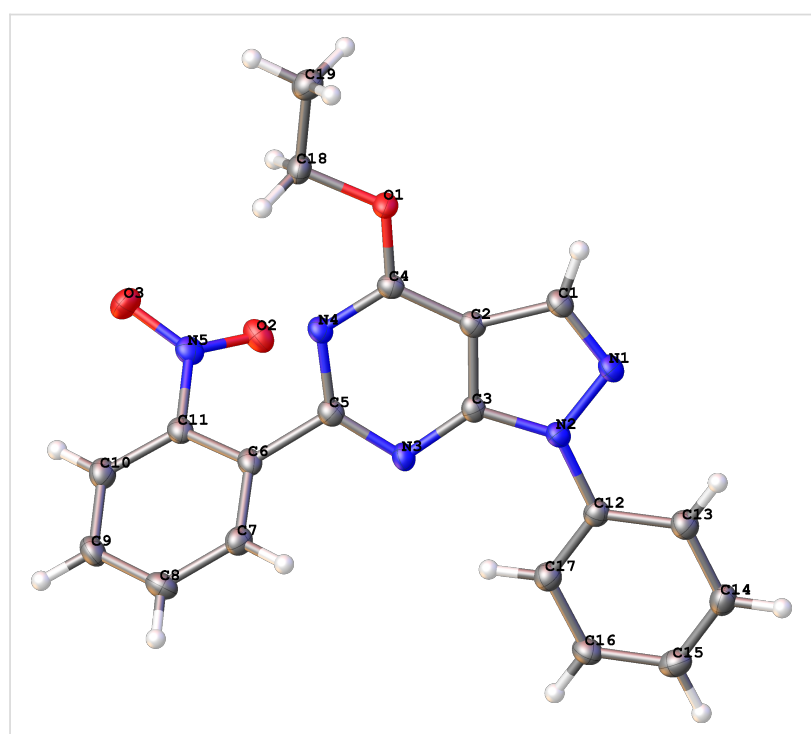

Figure 2: Molecular structure (from X-ray diffraction data) of $\mathbf{5 g}$.

\section{Conclusion}

In summary, we have disclosed an efficient one-pot fourcomponent synthesis of pyrazolo $[3,4-d]$ pyrimidines. The simplicity of execution, readily available substrates and the potentially important use of the products make this synthetic

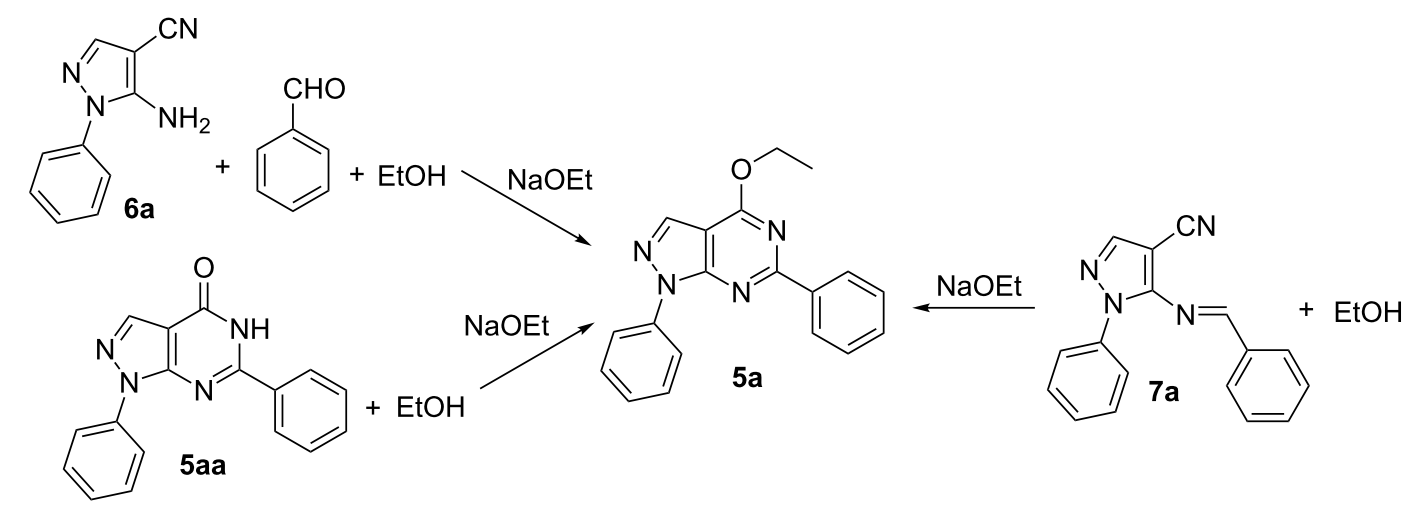


<smiles>[R]/C(C#N)=C(\[R])OCC</smiles><smiles>[R]ON=CC</smiles>

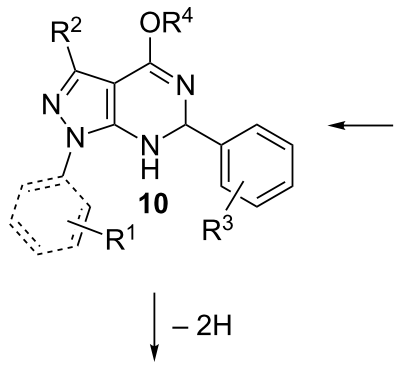<smiles>[R]OC(=N)c1c([R])nn(-c2ccccc2)c1/N=C/c1cccc([R])c1</smiles><smiles></smiles><smiles>[R][R]1cccc(C(O)Nc2c(C#N)c([R])nn2-c2ccccc2)c1</smiles><smiles>[R][R]c1ccccc1-c1nc(O[R1])c2c([R])nn(-c3cccc([R])c3)c2n1</smiles><smiles>[R4]Oc1nc(-c2cccc([R])c2)nc2c1c([R])nn2-c1cccc([R])c1</smiles><smiles>[R][R]c1cccc(C2Nc3c(c([R])nn3-c3cccc([R])c3)C(=N)O2)c1</smiles><smiles>[R][R]1cccc(-c2nc3c(c([R])nn3-c3cccc([R])c3)c(=O)[nH]2)c1</smiles><smiles>[R]c1cccc(C2NC(=O)c3c(nn(-c4cccc([R])c4)c3[R])N2)c1</smiles><smiles>[R][R]c1cccc(/C=N/c2c(C(N)=O)c([R])nn2-c2cccc([R])c2)c1</smiles>

Scheme 3: Possible reaction mechanisms for the formation of pyrazolo[3,4-d]pyrimidiine.

protocol attractive for academic research and practical applications. Further studies towards the detailed mechanism and synthetic application of this protocol are in progress.

\section{Supporting Information}

\section{Supporting Information File 1}

Experimental section and copies of ${ }^{1} \mathrm{H}$ and ${ }^{13} \mathrm{C}$ NMR spectra of compounds.

[http://www.beilstein-journals.org/bjoc/content/ supplementary/1860-5397-11-229-S1.pdf]

\section{Acknowledgements}

This work was supported by the Basic Research Foundation of Beijing Institute of Technology (20131042006). We are grateful for the analytical assistance from The Chinese Academy of
Agricultural Sciences, Peking University and Beijing University of Chemical Technology.

\section{References}

1. Schenone, S.; Radi, M.; Musumeci, F.; Brullo, C.; Botta, M. Chem. Rev. 2014, 114, 7189-7238. doi:10.1021/cr400270z

2. Parker, W. B. Chem. Rev. 2009, 109, 2880-2893. doi:10.1021/cr900028p

3. Martin, M. W.; Newcomb, J.; Nunes, J. J.; Boucher, C.; Chai, L.; Epstein, L. F.; Faust, T.; Flores, S.; Gallant, P.; Gore, A.; Gu, Y.; Hsieh, F.; Huang, X.; Kim, J. L.; Middleton, S.; Oliveira-dos-Santos, A.; Patel, V. F.; Powers, D.; Rose, P.; Tudor, Y.; Turci, S. M.; Welcher, A. A.; Zack, D.; Zhao, H.; Zhu, L.; Zhu, X.; Ghiron, C.; Ermann, M.; Johnston, D.; Saluste, C.-G. P. J. Med. Chem. 2008, 51, 1637-1648. doi:10.1021/jm701095m

4. Chauhan, M.; Kumar, R. Bioorg. Med. Chem. 2013, 21, 5657-5668. doi:10.1016/j.bmc.2013.07.027

5. Palanisamy, P.; Jenniefer, S. J.; Muthiah, P. T.; Kumaresan, S. RSC Adv. 2013, 3, 19300-19310. doi:10.1039/c3ra42283f 
6. Wang, L.; Zhou, X.; Fredimoses, M.; Liao, S.; Liu, Y. RSC Adv. 2014, 4, 57350-57376. doi:10.1039/C4RA09833A

7. Hsu, T. C.; Robins, R. K.; Cheng, C. C. Science 1956, 123, 848-849. doi:10.1126/science.123.3202.848-a

8. Hafez, T. S.; Osman, S. A.; Yosef, H. A. A.; Abd El-All, A. S.; Hassan, A. S.; El-Sawy, A. A.; Abdallah, M. M.; Youns, M. Sci. Pharm. 2013, 81, 339-357. doi:10.3797/scipharm.1211-07

9. Bahashwan, S. A.; Fayed, A. A.; Amr, A. E. E.; Flefel, E. M.; Kalmouch, A. Molecules 2013, 18, 15051-15063. doi:10.3390/molecules181215051

10. Nugent, R. A.; Dunn, C. J.; Staite, N. D.; Murphy, M. J.; Schlachter, S. T.; Aspar, D. G.; Shields, S. K.; Galinet, L. A. Phosphorus, Sulfur Silicon Relat. Elem. 1996, 109, 229-232. doi:10.1080/10426509608545132

11. Shamroukh, A. H.; Rashd, A. E.; Ali, H. S.; Abdel-Megeid, F. M. E. J. Heterocycl. Chem. 2013, 50, 758-765. doi:10.1002/jhet.1550

12. Holla, B. S.; Mahalinga, M.; Karthikeyan, M. S.; Akberali, P. M.; Shetty, N. S. Bioorg. Med. Chem. 2006, 14, 2040-2047. doi:10.1016/j.bmc.2005.10.053

13. Ali, A.; Taylor, G. E.; Ellsworth, K.; Harris, G.; Painter, R.; Silver, L. L.; Young, K. J. Med. Chem. 2003, 46, 1824-1830. doi:10.1021/jm020483c

14. Ram, V. J.; Pandey, H. N.; Mishra, L. Arch. Pharm. 1979, 312, 586-590. doi:10.1002/ardp.19793120705

15. Ghorab, M. M.; Ragab, F. A.; Alqasoumi, S. I.; Alafeefy, A. M.; Aboulmagd, S. A. Eur. J. Med. Chem. 2010, 45, 171-178. doi:10.1016/j.ejmech.2009.09.039

16. Xia, Y.; Chackalamannil, S.; Czarniecki, M.; Tsai, H.; Vaccaro, H.; Cleven, R.; Cook, J.; Fawzi, A.; Watkins, R.; Zhang, H. J. Med. Chem. 1997, 40, 4372-4377. doi:10.1021/jm970495b

17. Guccione, S.; Modica, M.; Longmore, J.; Shaw, D.; Barretta, G. U.; Santagati, A.; Santagati, M.; Russo, F. Bioorg. Med. Chem. Lett. 1996, 6, 59-64. doi:10.1016/0960-894X(95)00558-B

18. Todorovic, N.; Awuah, E.; Shakya, T.; Wright, G. D.; Capretta, A. Tetrahedron Lett. 2011, 52, 5761-5763. doi:10.1016/j.tetlet.2011.08.103

19. Da Settimo, F.; Primofiore, G.; La Motta, C.; Taliani, S.; Simorini, F.; Marini, A. M.; Mugnaini, L.; Lavecchia, A.; Novellino, E.; Tuscano, D.; Martini, C. J. Med. Chem. 2005, 48, 5162-5174. doi:10.1021/jm050136d

20. Kulkarni, A.; Quang, P.; Curry, V.; Keyes, R.; Zhou, W.; Cho, H.; Baffoe, J.; Török, B.; Stieglitz, K. Chem. Biol. Drug Des. 2014, 84, 270-281. doi:10.1111/cbdd.12319

21. El Hedi Jellali, M.; Van Bac, N.; Dat-Xuong, N. Tetrahedron 1975, 31 , 587-591. doi:10.1016/0040-4020(75)85034-4

22. La Motta, C.; Sartini, S.; Mugnaini, L.; Salerno, S.; Simorini, F.; Taliani, S.; Marini, A. M.; Da Settimo, F.; Lavecchia, A.; Novellino, E.; Antonioli, L.; Fornai, M.; Blandizzi, C.; Del Tacca, M. J. Med. Chem. 2009, 52, 1681-1692. doi:10.1021/jm801427r

23. Shamroukh, A. H.; Rashad, A. E.; Abdel-Megeid, R. E.; Ali, H. S.; Ali, M. M. Arch. Pharm. 2014, 347, 559-565. doi:10.1002/ardp.201400064

24. Semple, G.; Ren, A.; Fioravanti, B.; Pereira, G.; Calderon, I.; Choi, K.; Xiong, Y.; Shin, Y.-J.; Gharbaoui, T.; Sage, C. R.; Morgan, M.; Xing, C.; Chu, Z.-L.; Leonard, J. N.; Grottick, A. J.; Al-Shamma, H.; Liang, Y.; Demarest, K. T.; Jones, R. M. Bioorg. Med. Chem. Lett. 2011, 21, 3134-3141. doi:10.1016/j.bmcl.2011.03.007

25. Kreutzberger, A.; Burgwitz, K. Eur. J. Med. Chem. 1979, 14, 539-544.
26. Bacon, E. R.; Bailey, T.; Becknell, N. C.; Gingrich, D. E.; Hostetler, G.; Hudkins, R. L.; Learn, K. S.; Wagner, J. C. Substituted pyrazolopyrimidines. U.S. Patent US20070281949, Dec 6, 2007.

27. Salaheldin, A. M.; Oliveira-Campos, A. M. F.; Rodrigues, L. M. Synth. Commun. 2009, 39, 1186-1195. doi:10.1080/00397910802517814

28. Biggadike, K.; House, D.; Inglis, G. G. A.; Macdonald, S. J. F.; Mclay, I. M.; Skone, P. A. Pyrazolo-pyrimidine derivatives as anti-inflammatory agents. PCT Patent WO2007054294, May 18, 2007.

29. Zhang, L.-J.; Shi, D.-X.; Li, J.-R. Synth. Commun. 2009, 39, 4010-4018. doi:10.1080/00397910902883629

30. Liu, M.; Li, J.; Chen, S.; Huang, D.; Chai, H.; Zhang, Q.; Shi, D. RSC Adv. 2014, 4, 35629-35634. doi:10.1039/C4RA05346J

31. Baraldi, P. G.; Pavani, M. G.; del Carmen Nuñez, M.; Brigidi, P.; Vitali, B.; Gambari, R.; Romagnoli, R. Bioorg. Med. Chem. 2002, 10, 449-456. doi:10.1016/S0968-0896(01)00294-2

32. Anderson, J. D.; Cottam, H. B.; Larson, S. B.; Nord, L. D.; Revankar, G. R.; Robins, R. K. J. Heterocycl. Chem. 1990, 27 , 439-453. doi:10.1002/jhet.5570270262

33. Wamhoff, H.; Ertas, M.; Atta, S. M. S. Liebigs Ann. Chem. 1985, 1910-1916. doi:10.1002/jlac.198519850918

34. Schmidt, P.; Eichenberger, K.; Druey, J. Helv. Chim. Acta 1958, 41, 1052-1060. doi:10.1002/hlca.19580410418

35. Ferroni, R.; Simoni, D.; Orlandini, P.; Bardi, A.; Franze, G. P.; Guarneri, M. Arzneim. Forsch. 1990, 40, 1328-1331.

36. Cheng, C. C.; Robins, R. K. J. Org. Chem. 1958, 23, 852-861. doi:10.1021/jo01100a025

37. Miyashita, A.; lijima, C.; Higashino, T.; Matsuda, H. Heterocycles 1990, 31, 1309-1314. doi:10.3987/COM-90-5407

38. Tavakoli-Hoseini, N.; Moloudi, R.; Davoodnia, A.; Shaker, M. Chin. J. Chem. 2011, 29, 2421-2426. doi:10.1002/cjoc.201180411

39. Zhang, X. Q.; Abad, M. G.; Gibbs, A. C.; Kuo, G.-H.; Kuo, L. C.; Song, F.; Sui, Z. Indazole compounds useful as ketohexokinase inhibitors. U.S. Patent US20110263559, Oct 27, 2011.

40. Xu, L. Pyrimidine derivatives and analogs, preparation method and use thereof. U.S. Patent US20120178915, July 12, 2012.

41. Chang, C.-H.; Tsai, H. J.; Huang, Y.-Y.; Lin, H.-Y.; Wang, L.-Y.; Wu, T.-S.; Wong, F. F. Tetrahedron 2013, 69, 1378-1386. doi:10.1016/j.tet.2012.11.002

42. Simay, A.; Takacs, K.; Horvath, K.; Dvortsak, P. Acta Chim. Acad. Sci. Hung. 1980, 105, 127-139.

43. Srivastava, M.; Rai, P.; Singh, J.; Singh, J. RSC Adv. 2013, 3, 16994-16998. doi:10.1039/c3ra42493f

44. Bobko, M. A.; Kaura, A. C.; Evans, K. A.; Su, D.-S. Org. Lett. 2012, 14, 3906-3908. doi:10.1021/ol301655f

45. Apsel, B.; Blair, J. A.; Gonzalez, B.; Nazif, T. M.; Feldman, M. E.; Aizenstein, B.; Hoffman, R.; Williams, R. L.; Shokat, K. M.; Knight, Z. A. Nat. Chem. Biol. 2008, 4, 691-699. doi:10.1038/nchembio.117

46. Meng, F.; Hou, J.; Shao, Y.-X.; Wu, P.-Y.; Huang, M.; Zhu, X.; Cai, Y.; Li, Z.; Xu, J.; Liu, P.; Luo, H.-B.; Wan, Y.; Ke, H. J. Med. Chem. 2012, 55, 8549-8558. doi:10.1021/jm301189c

47. Harden, F. A.; Quinn, R. J.; Scammells, P. J. J. Med. Chem. 1991, 34, 2892-2898. doi:10.1021/jm00113a031

48. Liu, J.; Zhang, X.-w.; Wang, Y.; Chen, Y.; Zhang, M.-r.; Cai, Z.-q.; Zhou, Y.-p.; Xu, L.-f. Synth. Commun. 2015, 45, 1009-1017. doi:10.1080/00397911.2014.996296

49. Liu, C.; Yu, Q.; Tang, J.; Li, J. Chin. J. Org. Chem. 2012, 32, 532-537. doi:10.6023/cjoc1108102 
50. Full details have been deposited the Cambridge Crystallographic Data Centre as supplementary publication no. CCDC-1401076. Copies of the datacan be obtained, free of charge, on application to CCDC, 12 Union Road, Cambridge CB2 1EZ, UK (fax: $+44(0)-1223336033$ or e-mail: deposit@ccdc.cam.ac.uk).

\section{License and Terms}

This is an Open Access article under the terms of the Creative Commons Attribution License

(http://creativecommons.org/licenses/by/2.0), which permits unrestricted use, distribution, and reproduction in any medium, provided the original work is properly cited.

The license is subject to the Beilstein Journal of Organic Chemistry terms and conditions:

(http://www.beilstein-journals.org/bjoc)

The definitive version of this article is the electronic one which can be found at: doi:10.3762/bjoc.11.229 